\title{
Assessment of Cost-Benefit for a Net Metering Scheme based on Solar PV: Case Study on a University Campus located in Lima-Peru.
}

\author{
Caroline Camarena-Gamarra ${ }^{1}$, José Calle-Maravi, Ph.D. ${ }^{2}$, Johnny Nahui-Ortiz, Ph.D. ${ }^{1}$ \\ ${ }^{1}$ National University of Engineering, Peru, ccamarenag@uni.pe, jnahuio@uni.edu.pe \\ ${ }^{2}$ National Agrarian University La Molina, Peru, jcalle@lamolina.edu.pe
}

\begin{abstract}
A net metering scheme based on a 3.25-kWp Photovoltaic System was setup within the facilities of a university campus located in Lima-Peru for evaluation purposes. Solar PV system output as well as energy demand were registered for the entire year 2019. The contribution of solar $P V$ production to total electricity demand is analyzed, considering seasonal variations in both the PV production and the energy consumption within the period of one year.

Total implementation cost was calculated by adding CAPEX and OPEX values for a $3.25-k W p$ solar PV system operating under local conditions. In this case, total investment cost for the PV systems is estimated as 4,063 US\$ while annual O\&M costs are estimated as 71 US\$.

Considering a local electricity tariff of $0.15 \mathrm{US} \$ \mathrm{kWh}$ for the end user, annual cost savings is $1068 \mathrm{US} / \mathrm{yr}$ and the overall simple payback turns out to be 4.3 years. Therefore, it can be expected that potential introduction of a net metering squeme may become attractive for end users under local market conditions.
\end{abstract}

Keywords-Educational Facility, Energy Demand, PV Electricity, Cost-Benefit analysis, Environmental Management.

\section{INTRODUCTION}

Net metering based on solar on-grid PV systems at small scale is getting increased attention worldwide. In Peru, such squeme has not yet been implemented but expectations are high. In October 2015, Law Decree $\mathrm{Nr} 1221$ stated an official definition for Distributed Generation; however, regulations for its commercial introduction are still in progress.

A small scale on-grid solar PV system was installed in the National Agrarian University La Molina (UNALM) located in Lima, Peru. Using its embedded monitoring system, solar PV energy production, as well as energy demand in one of the buildings, has been monitored all year long.

The research group is interested here in finding out how a solar PV system, connected to the grid, would perform under local weather conditions in a potential net metering squeme. And, how beneficial it might be for an end user under local current electricity tariffs.

\section{BACKGROUND}

In Ref. [1], in this study, several alternative policy options were assessed on the financial case for private homeowners investing in a PV system (simple payback time), on purchasing behavior (using a technology adoption model), and on governmental costs. While continuation of net metering policy

Digital Object Identifier (DOI):

http://dx.doi.org/10.18687/LACCEI2020.1.1.233

ISBN: 978-958-52071-4-1 ISSN: 2414-6390 leads to ongoing improvement of the financial case up to levels that could be considered overstimulation, three policy alternatives can be set up so that they stabilize simple payback times of recent and future generations of PV systems. Under these alternative instruments, deployment of PV systems in this market segment is indicatively estimated to be $15-20 \%$ lower by the year 2030 than with continuation of net metering policy, while corresponding governmental cost reduction indications would be more than $50 \%$.

In Ref. [2], the policy of net metering allows operators of residential- and commercial solar PV systems to sell surplus electricity back to their utility at the going retail rate. This policy has recently been criticized on the grounds that it provides a subsidy for residential and commercial solar installations, a subsidy that is paid for by all ratepayers. In response, public utility commissions have begun to take up this regulatory issue.

In Ref. [3], the present work examines the impact on consumer electricity bills under five different cases based on different compensation mechanisms to evaluate PV generation units for 120 residential consumers, for assessing the pertinence of energy policy to be introduced for encouraging rooftop PV in India. The consumers are categorized based on their lifestyles. It is found that lower the size of the panel, lower is the savings leading to a decrease in the attractiveness of a rooftop PV system for a residential consumer. Also, the compensation mechanism and injection tariff play a crucial role in making a rooftop PV system feasible for a residential consumer. It is observed that the achieved savings of a consumer is a function of compensation mechanism and seasonal load pattern of a consumer.

In Ref. [4], with the continued growth of distributed power generation, the number of customers who consume and produce energy via solar photovoltaic (PV) power generation (solar prosumers) has been increasing. Unfortunately, electric utilities are not aware of the location of all solar prosumers due to unauthorized or unreported installations and lack of separate PV metering in areas with Net Energy Metering policies. Knowledge of the location of solar prosumers can inform circuit protection and voltage regulation settings, and help grid operators improve situational awareness and better plan for daily variations in demand, which are further magnified by generation intermittency.

In Ref. [5], as the cost of solar photovoltaic (PV) systems decreases and incentives such as feed-in tariffs (FiTs) are offered, solar-PV homes are becoming popular. Furthermore, solar-PV homes integrated with hybrid or electric vehicles (EVs) 
are emerging as a paradigm for future homes. Given the fact that there exists a considerable price difference between grid electricity supply and FiTs, decision making of energy storage using batteries becomes an imperative topic.

In Ref. [6], it is investigated the impact of retail rate design on the investment incentives, avoided utility costs, and costshifting concerns associated with rooftop solar plus battery storage systems that are located behind-the-meter. To illustrate these interactions, the authors consider recently proposed changes time-of-use pricing policy for commercial and industrial consumers which shifts on-peak prices from midday to the constrained evening hours. It is found that these rate adjustments reduce cost-shifting concerns across consumers considerably, but also decreases solar PV investment and has an ambiguous effect on storage investment.

In Ref. [7], in a climate of soaring energy prices not all consumers are able to afford the upfront investment costs in photovoltaics to manage their energy costs. Virtual Net Metering enables the sharing of generation and storage benefits against the load of decentralized customers including apartments. The aggregation of resources can reduce the cost for monitoring and managing distributed generation. This is possible by the use of innovative technology for monitoring, billing and settlement software.

In Ref. [8], significant growth of behind-the-meter solar Photovoltaic (PV) power generation in recent years is changing the shape of the net demand for electricity from electrical grids. In this work, a framework is proposed to forecast the aggregated power generation of a large fleet of small behind-the-meter solar PV sites. The outputs of those sites are not individually measured and thus, the aggregated output is "invisible" to power system operators.

In Ref. [9], this study addresses the terms, conditions and effectiveness of policies reflected as the inter-annual growth in PV power production with respect to the potential realizable capacity in the country. Additionally, a life cycle cost and greenhouse gas (GHG) emission reduction analysis is presented to demonstrate the economic viability and environmental impact of implementing an on-grid residential PV installation in the country.

\section{ELECTRICITY MARKET IN PERU}

\section{A. Electricity generation mix}

The electricity sector of Peru is composed by generation, transmission, distribution, and end-users, as it is normally elsewhere.

According to last official reports, as from 2018, electricity was produced mainly by: thermal power plants $(37.82 \%)$, hydropower plants $(57.77 \%)$, solar power plants $(1.47 \%)$, and wind power plants $(2.94 \%)$.

It is important to mention that, in Peru, natural gas became a major player in the generation mix as from 2004. Before that, the country use to generate electricity by using centralized hydropower plants.
Also, renewable energy, including solar, wind, and others, started to enter into the electricity market in 2010 .

Table I shows electric power generation registered in 2018.

TABLE I

\begin{tabular}{|c|c|c|}
\hline \multicolumn{3}{|c|}{ Electric Power Generation by Type in $\mathbf{2 0 1 8}$} \\
\hline Type & Energy (GWh) & Participation (\%) \\
\hline Hydropower & $29,357.9$ & 57.77 \\
\hline Thermal & $19,220.0$ & 37.82 \\
\hline Solar & 745.2 & 1.47 \\
\hline Wind & $1,493.6$ & 2.94 \\
\hline Total & $\mathbf{5 0 , 8 1 6 . 8}$ & $\mathbf{1 0 0}$ \\
\hline
\end{tabular}

Source: Operations Statistics 2018 COES

Thermal power plants are run on different fossil fuels depending on the technology involved. It is important to mention that, in Peru, most of the electricity produced by thermal power plants comes from combined cycle units that run on natural gas.

Table II shows thermal power production by technology in 2018.

TABLE II

\begin{tabular}{|c|c|c|}
\hline \multicolumn{2}{|c|}{ Thermal Power Production by Technology in $\mathbf{2 0 1 8}$} \\
\hline Type & Energy $\mathbf{( G W h )}$ & $\begin{array}{c}\text { Participation } \\
\mathbf{( \% )}\end{array}$ \\
\hline Combined Cycle & $16,550.4$ & 86.11 \\
\hline Gas Turbine & $2,299.5$ & 11.96 \\
\hline Steam Turbine & 161.6 & 0.84 \\
\hline Diesel Engine & 208.5 & 1.09 \\
\hline Total & $\mathbf{1 9 , 2 2 0 . 0}$ & $\mathbf{1 0 0}$ \\
\hline
\end{tabular}

Source: Operation Statistics in 2018 COES

The following figure highlights the major role played nowadays by combined cycle technologies in the electricity mix of Peru.

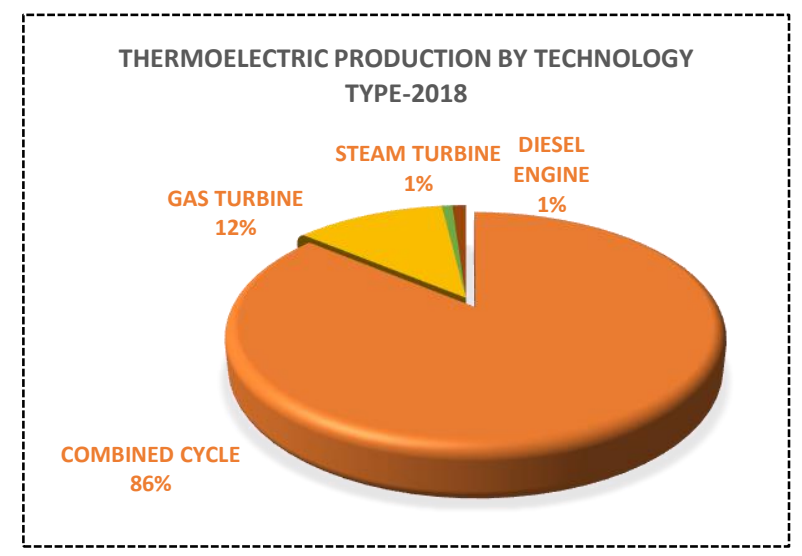

Fig. 1: Thermal Power Production by Technology in 2018

Energy demand has been increasing in the last decade at a moderate pace. Maximum demand was registered on December 17, 2018 at 19h45. Table III, shows electricity generation used during peak demand. 
TABLE III

\begin{tabular}{|c|c|}
\hline \multicolumn{2}{|c|}{$\begin{array}{c}\text { Maximum Demand by Technology Type (Dec. } \\
18,2018 \text { at } 19 \mathrm{~h} 45 \text { ) }\end{array}$} \\
\hline TECHNOLOGY TYPE & TOTAL (MW) \\
\hline Hydroelectric & $3,972.2$ \\
\hline Wind & 247.1 \\
\hline Combined cycle & $2,474.2$ \\
\hline Gas turbine & 116.3 \\
\hline Steam turbine & 47.3 \\
\hline Diesel Engine & 27.5 \\
\hline Total & $6,884.6$ \\
\hline
\end{tabular}

Source: Operation Statistics in 2018 COES

Minimum power was registered in January and accounted for 4,025 MW. Maximum power was registered in December and accounted for 6,928 MW. Maximum power during pick hours were registered in December and accounted for 6,885 MW. Total annual energy production reached 50,817 GWh with an overall average load factor of 0.837 . Table IV shows monthly power demand, energy production and load factor for the year 2018 .

\begin{tabular}{|c|c|c|c|c|c|}
\multicolumn{7}{|c|}{ Load Factor in 2018 } \\
\hline Month & $\begin{array}{c}\text { Min } \\
\text { Power } \\
\text { (MW) }\end{array}$ & $\begin{array}{c}\text { Max } \\
\text { Power } \\
\text { (MW) }\end{array}$ & $\begin{array}{c}\text { Max } \\
\text { Power } \\
\text { During } \\
\text { Pick } \\
\text { Hours } \\
\text { (MW) }\end{array}$ & $\begin{array}{c}\text { Energy } \\
\text { Production } \\
\text { (GWh) }\end{array}$ & $\begin{array}{c}\text { Load } \\
\text { Factor }\end{array}$ \\
\hline Jan & 4025 & 6592 & 6489 & 4255.25 & 0.868 \\
\hline Feb & 4582 & 6719 & 6577 & 3919.54 & 0.868 \\
\hline Mar & 4546 & 6670 & 6640 & 4315.87 & 0.870 \\
\hline Apr & 4603 & 6711 & 6711 & 4207.90 & 0.871 \\
\hline May & 4501 & 6617 & 6617 & 4287.98 & 0.871 \\
\hline Jun & 4518 & 6542 & 6542 & 4134.92 & 0.878 \\
\hline Jul & 4286 & 6443 & 6463 & 4200.01 & 0.876 \\
\hline Aug & 4557 & 6519 & 6519 & 4221.87 & 0.870 \\
\hline Sep & 4614 & 6554 & 6554 & 4143.36 & 0.878 \\
\hline Oct & 4622 & 6658 & 6658 & 4354.59 & 0.879 \\
\hline Nov & 4795 & 6786 & 6786 & 4279.41 & 0.876 \\
\hline Dec & 4304 & 6928 & 6885 & 4496.08 & 0.872 \\
\hline Total & $\mathbf{4 , 0 2 5}$ & $\mathbf{6 , 9 2 8}$ & $\mathbf{6 , 8 8 5}$ & $\mathbf{5 0 , 8 1 6 . 7 9}$ & $\mathbf{0 . 8 3 7}$ \\
\hline
\end{tabular}

\section{B. End-use electricity consumption}

According to last official reports, 2017, electricity was consumed mainly by: residential $(21 \%)$, commercial $(17 \%)$, industrial (25\%), and mining (32\%) sectors. All together, they represent approximately $91 \%$ of total electricity consumption in the country.

The following figure shows electricity consumed by different sectors in the year 2017.

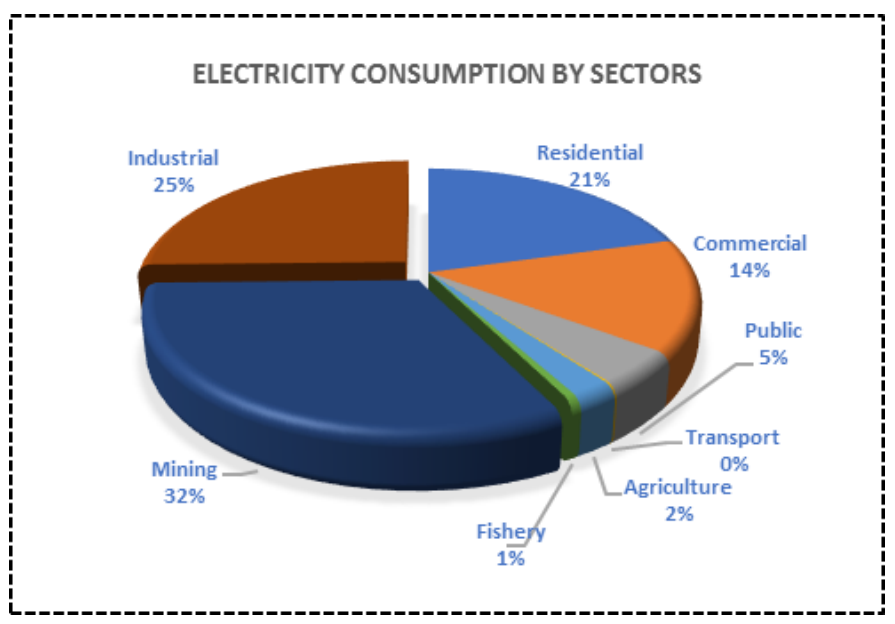

Fig. 2: Electricity consumption by sectors in 2017 Source: National Energy Balance 2017 MINEM

Most of the energy was consumed by the mining sector followed by the industrial and residential sector. Table IV shows electricity consumption by each sector in 2017 .

TABLE IV

\begin{tabular}{|c|c|}
\hline \multicolumn{2}{|c|}{ Electricity Consumption by sectors in 2017} \\
\hline Sector & Consumption (GWh) \\
\hline Residential & 9573.4 \\
\hline Commercial & 6741.1 \\
\hline Public & 2106.6 \\
\hline Transportation & 53.1 \\
\hline Agriculture & 1015.9 \\
\hline Fishery & 258.5 \\
\hline Mining & 14946.3 \\
\hline Industrial & 11769.9 \\
\hline Total & 46464.8 \\
\hline
\end{tabular}

Source: National Energy Balance 2017-MINEM

\section{PV ELECTRICITY PRODUCTION}

\section{A. Solar PV System}

A 3.25-kWp solar PV system, installed on a university campus located in the city of Lima, was considered for evaluation purposes. The solar PV system, contains PV modules, inverters, controllers, and a monitor. The following figure shows the solar PV system considered for this work.

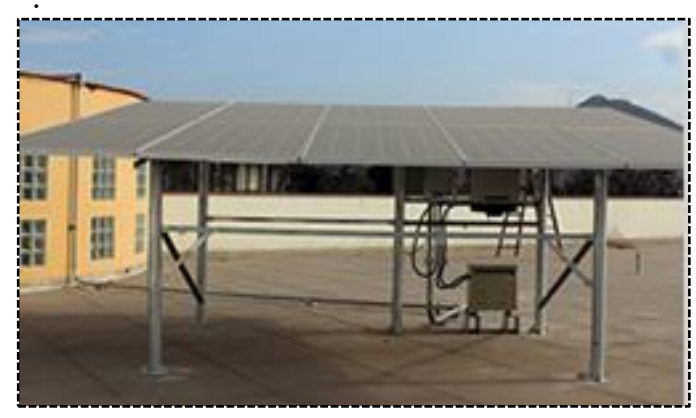

Fig. 3. A 3.25-kWp Solar PV System Source: Sunny Portal Web 
Table V shows technical specification for the PV Module. Model Module: Canadian Solar Inc. CS6U-325P.

TABLE V

\begin{tabular}{|l|c|}
\hline \multicolumn{2}{|c|}{ Mechanical Data } \\
\hline Specifications & Data \\
\hline Cell Type & Poly-crystalline, 6inch \\
\hline Cell Arrangement & $72(6 \times 12)$ \\
\hline Dimensions & $\begin{array}{c}1960 \times 992 \times 40 \mathrm{~mm} \\
(77.2 \times 39.1 * 1.57 \mathrm{in})\end{array}$ \\
\hline Weight & $22.4 \mathrm{Kg}(49.4 \mathrm{lbs})$ \\
\hline Front cover & $3.2 \mathrm{~mm}$ tempered glass \\
\hline Frame material & Anodized aluminum alloy \\
\hline J-Box & IP67,3diodes \\
\hline Cable & $\begin{array}{c}4 \mathrm{~mm} 2 \text { (IEC)OR 4 MM2 \&12AWG } \\
1000 \mathrm{~V}(\mathrm{UL}), 1160 \mathrm{~mm}(45.7 \mathrm{in})\end{array}$ \\
\hline Connector & T4series or PV2 series \\
\hline Per Pallet & 26 pieces, 635 Kg (1400lbs) \\
\hline $\begin{array}{l}\text { Per container } \\
\text { (40'HQ) }\end{array}$ & 624 pieces \\
\hline
\end{tabular}

Table VI shows technical specifications for the Inverter. Model Inverter: Sunny Tripower 5000TL-20. Monitor is Sunny Home Manager 2.0.

TABLE VI

\begin{tabular}{|c|c|}
\hline \multicolumn{2}{|c|}{ Technical Data } \\
\hline Input (DC) & Sunny Tripower 5000TL \\
\hline Cell Type & $9000 \mathrm{Wp}$ \\
\hline Cell Arrangement & $1000 \mathrm{~V}$ \\
\hline Dimensions & $245 \mathrm{~V}$ to $800 \mathrm{~V} / 580 \mathrm{~V}$ \\
\hline Weight & $150 \mathrm{~V} / 188 \mathrm{~V}$ \\
\hline Front cover & $11 \mathrm{~A} / 10 \mathrm{~A}$ \\
\hline Frame material & $17 \mathrm{~A} / 15 \mathrm{~A}$ \\
\hline J-Box & IP2/A:2; B:2 \\
\hline \multicolumn{2}{|l|}{ Output (AC) } \\
\hline $\begin{array}{l}\text { Rated power (at } \\
230 \mathrm{~V}, 50 \mathrm{~Hz} \text { ) }\end{array}$ & $5000 \mathrm{~W}$ \\
\hline Max. AC apparent power & $5000 \mathrm{VA}$ \\
\hline Nominal AC voltage & $3 / \mathrm{N} / \mathrm{PE} ; 230 / 400 \mathrm{~V}$ \\
\hline AC grid frequency/range & $50 \mathrm{~Hz} /+-5 \mathrm{~Hz}$ \\
\hline $\begin{array}{l}\text { Rated power } \\
\text { frequency/rated grid } \\
\text { voltage }\end{array}$ & $50 \mathrm{~Hz} / 230 \mathrm{~V}$ \\
\hline Max,output current & $7.3 \mathrm{~A}$ \\
\hline $\begin{array}{l}\text { Power factor at rated } \\
\text { power }\end{array}$ & 1 \\
\hline $\begin{array}{l}\text { Adjustable displacement } \\
\text { power factor }\end{array}$ & $\begin{array}{c}0.8 \text { overexcited to } 0.8 \\
\text { underexcited }\end{array}$ \\
\hline $\begin{array}{l}\text { Feed in phases/connection } \\
\text { phases }\end{array}$ & $3 / 3$ \\
\hline $\begin{array}{l}\text { Max efficiency/European } \\
\text { efficiency }\end{array}$ & $98 \% / 97.1 \%$ \\
\hline
\end{tabular}

\section{B. Data Collected}

Data for 2019 was downloaded from a virtual platform. Information about solar photovoltaic production and electric grid consumption is recorded every 15 minutes during 24 hours per day and 365 days per year.

The average power was registered each 15 minutes during each month; however, during Jan. 22-23, Mar. 8, April 23-25, and May 9-14, data was not recorded properly.

Solar photovoltaic production $(\mathrm{kWh})$ was calculated for every 15 minutes, based on the average power demand. Finally, total monthly energy production is obtained for the year 2019 .

\section{PV Electricity Production}

The PV electricity production has been changing along the year. The maximum production was registered in March and the minimum in July. Table VII shows monthly solar PV production in $\mathrm{kWh}$.

TABLE VII

\begin{tabular}{|c|c|}
\hline Month & PV Production (kWh/day) \\
\hline January & 14.3215 \\
\hline February & 14.8828 \\
\hline March & 16.3533 \\
\hline April & 15.0536 \\
\hline May & 7.2395 \\
\hline June & 5.1556 \\
\hline July & 5.0351 \\
\hline August & 8.0960 \\
\hline September & 10.6789 \\
\hline October & 13.4840 \\
\hline November & 13.5656 \\
\hline December & 12.5280 \\
\hline
\end{tabular}

The following figure shows hourly solar PV production for an average day in March. Solar PV production starts about 06h15 and stops about $18 \mathrm{~h} 15$.

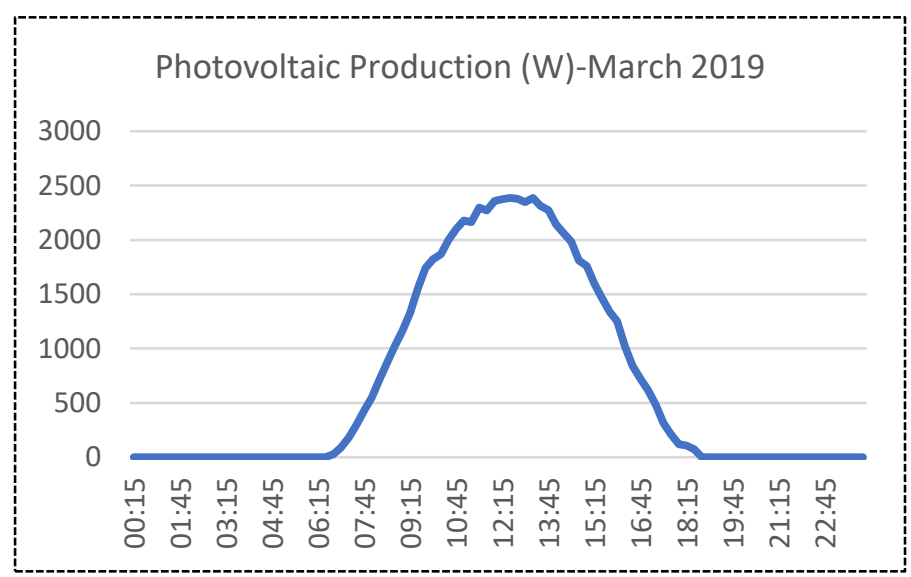

Fig. 5: Average Photovoltaic Production(W) in March 2019 Source: Own elaboration 
The following figure shows hourly solar PV production for an average day in July. Solar PV production starts about 06h45 and stops about $17 \mathrm{~h} 45$.

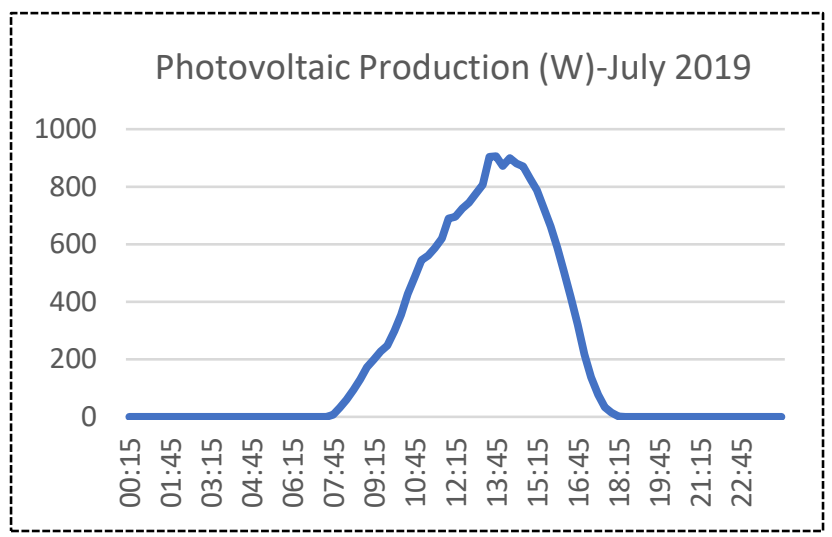

Fig. 6: Average Photovoltaic Production(W) July 2019 Source: Own elaboration

\section{ENERGY CONSUMPTION}

\section{A. Data Collected}

Data for 2019 was downloaded from a virtual platform. Information about solar photovoltaic production and electric grid consumption is recorded every 15 minutes during 24 hours per day and 365 days per year.

The average power was registered each 15 minutes during each month; however, during Jan. 22-23, Mar. 8, April 23-25, and May 9-14, data was not recorded properly.

Energy consumption $(\mathrm{kWh})$ was determined for every 15 minutes, based on the average power demand. Finally, total monthly energy consumption is obtained for the year 2019 .

\section{B. Energy Consumption}

Energy consumption has been changing along the year, the maximum energy consumption was in May and the minimum in August. Table VIII shows monthly energy consumption.

TABLE VIII

\begin{tabular}{|l|c|}
\hline Month & $\begin{array}{c}\text { Energy Consumption } \\
(\mathbf{k W h} / \text { day })\end{array}$ \\
\hline January & 20.9893 \\
\hline February & 21.2235 \\
\hline March & 22.8454 \\
\hline April & 22.1991 \\
\hline May & 23.2051 \\
\hline June & 18.8904 \\
\hline July & 16.4733 \\
\hline August & 16.3154 \\
\hline September & 18.7167 \\
\hline October & 21.4957 \\
\hline November & 21.6752 \\
\hline December & 20.4894 \\
\hline
\end{tabular}

The following figure shows hourly energy consumption for an average day in May. Maximum power demand occurs at about noon. In Lima, during May mild temperatures are registered (autumn).



Fig. 7: Energy Consumption (W) in May 2019 Source: Own elaboration

The following figure shows hourly energy consumption for an average day in August. Maximum power demand occurs also at about noon. In Lima, during August lower temperatures are registered (winter).

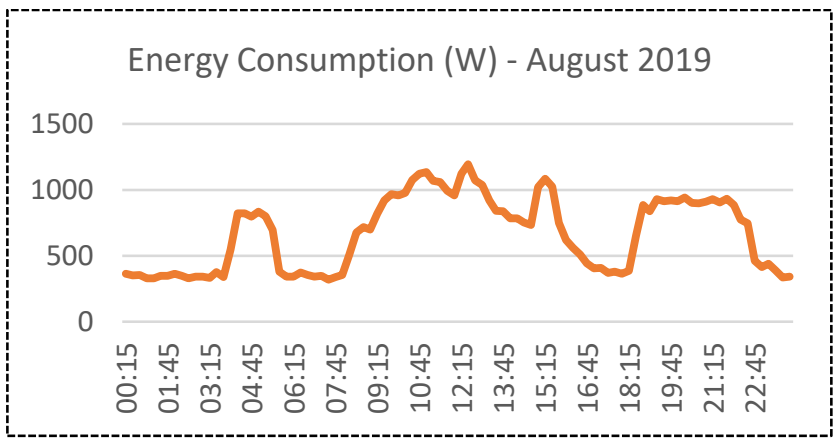

Fig. 8: Consumption (W)-August 2019 Source: Own elaboration

C. Energy Savings

To sum up, Table IX shows monthly energy savings.

TABLE IX

\begin{tabular}{|c|c|c|c|}
\hline Month & $\begin{array}{c}\text { PV Production } \\
(\mathbf{k W h})\end{array}$ & $\begin{array}{c}\text { Energy } \\
\text { Consumption }(\mathbf{k W h})\end{array}$ & $\begin{array}{c}\text { Energy Savings } \\
(\mathbf{k W h})\end{array}$ \\
\hline January & 14.3215 & 20.9893 & -6.6678 \\
\hline February & 14.8828 & 21.2235 & -6.3406 \\
\hline March & 16.3533 & 22.8454 & -6.4921 \\
\hline April & 15.0536 & 22.1991 & -7.1455 \\
\hline May & 7.2395 & 23.2051 & -15.9657 \\
\hline June & 5.4048 & 18.8904 & -13.4856 \\
\hline July & 5.0351 & 16.4733 & -11.4382 \\
\hline August & 8.0960 & 16.3154 & -8.2194 \\
\hline September & 10.6789 & 18.7167 & -8.0378 \\
\hline October & 13.4840 & 21.4957 & -8.0117 \\
\hline November & 13.5656 & 21.6752 & -8.1096 \\
\hline December & 12.5280 & 20.4894 & -7.9614 \\
\hline
\end{tabular}




\section{COST SAVINGS AND PAYBACK}

Capital investment cost for implementation of an on-grid PV system depends on installed capacity among other things. CAPEX unit cost for a $3.25-\mathrm{kWp}$ can be estimated as 1,250 $\mathrm{US} \$ \mathrm{kWp}$.

Annual operation and maintenance costs for an on-grid PV System depends on complexity of the system and distance to reach the on-site installation, among other things. For a system located in the city of Lima and with the technical characteristics described above, OPEX unit cost can be estimated as 0.01 $\mathrm{US} \$ / \mathrm{kWh}$.

LCOE, the Levelized Cost Of Energy, takes into account both CAPEX and OPEX during the entire project life. Replacement of components (controllers, inverters, and the kind) is also included in the capital investment cost.

In this case, project life will be considered as 20 years. Local financial institutions usually consider an annual discount rate of $12 \%$ for energy projects. Considering such discount rate and project horizon, an annuity factor (P/A) equal to 7.469 is obtained.

Then, total CAPEX cost is 4,063 US\$. Considering a solar PV production of $7,118 \mathrm{kWh} / \mathrm{yr}$, OPEX cost turns out be 71 US\$/yr, and using the above annuity factor, it becomes 532 US\$. Total cost for the solar PV system is therefore 4,594 US\$.

Total energy to be produced by the solar PV system, in 20 years, is $142,350 \mathrm{kWh}$. The LCOE value in this case is 0.032 US $\$ / k W h$. Local end-user electricity tariff is about 0.15 $\mathrm{US} \$ \mathrm{kWh}$, which is higher than the LCOE value found in this case.

So, the end user invests a total of 4,594 US and achieves a cost savings of $1,068 \mathrm{US} \$ / \mathrm{yr}$. Therefore, overall simple payback is 4.3 years.

\section{CONCLUSIONS}

PV electricity production varies as a function of solar irradiation throughout the entire year. The highest monthly electricity production reached $16.35 \mathrm{kWh} /$ day and was registered in March. On the other hand, the lowest monthly electricity production reached $5.03 \mathrm{kWh} /$ day and was registered in July.

Energy consumption also varies as a function of campus activities throughout the entire year. The highest monthly energy consumption accounted for $23.20 \mathrm{kWh} /$ day and was registered in May. On the other hand, the lowest monthly energy consumption accounted for $16.31 \mathrm{kWh} /$ day and was registered in August.

In terms of investment cost for the PV System, 4,063 US\$ was considered as CAPEX while $71 \mathrm{US} \$ \mathrm{yr}$ was considered as OPEX. Thus, considering a discount rate of $12 \%$ and a project life of $20 \mathrm{yr}$, LCOE is determined as $0.032 \mathrm{US} \$ / \mathrm{kWh}$.

Energy savings associated with solar PV generation for the entire year 2019 was $7,118 \mathrm{kWh}$. Considering an end-user electricity tariff of $\$ 0.15 / \mathrm{kWh}$, total annual cost savings represents 1,068 US $\$$ yr. Therefore, considering a total implementation cost of 4,594 US\$, an overall payback period of 4.3 years is obtained.

\section{ACKNOWLEDGMENT}

The authors would like to thank the staff members and authorities of the National Agrarian University La Molina, in Lima-Peru, for sharing their time and experience with the research team in order to facilitate data collection. The authors would also like to thank to all the people that, in one way or another, contributed to the present work.

\section{REFERENCES}

[1] LONDO, M. et al. 2020. Alternatives for current net metering policy for solar PV in the Netherlands: A comparison of impacts on business case and purchasing behaviour of private homeowners, and on governmental costs. ECN Energy research Centre of the Netherlands. Amsterdam, the Netherlands.

[2] COMELLO, S. et al. 2017. Cost competitiveness of residential solar PV: The impact of net metering restrictions. Stanford Graduate School of Business, United States.

[3] THAKUR, J.et al. 2019. Impact of compensation mechanisms for PV generation on residential consumers and shared net metering model for developing nations: A case study of India. Rajendra Mishra School of Engineering Entrepreneurship, Indian Institute of Technology, Kharagpur, India.

[4] DONALDSON, D.et al. 2020. Effective solar prosumer identification using net smart meter data. University of Birmingham, Birmingham, United Kingdom.

[5] LI, H. et al. 2020. Informed decision making of battery storage for solar-PV homes using smart meter data. School of Architecture and Built Environment, Deakin University, Australia.

[6] BOAMPONG, R. et al. 2020. On the benefits of behind-the-meter rooftop solar and energy storage: The importance of retail rate design. Department of Economics, University of Alberta, Alberta, Canada.

[7] SHAW-WILLIAMS, D. et al. 2020. A techno-economic evaluation of Virtual Net Metering for the Australian community housing sector. Queensland University of Technology, Science and Engineering Faculty, Brisbane City, Australia.

[8] SHAKER, H. et al. 2020. Forecasting the aggregated output of a large fleet of small behind-the-meter solar photovoltaic sites. University of Calgary, Canada.

[9] FARIAS-ROCHA, A. et al. 2019. Solar photovoltaic policy review and economic analysis for on-grid residential installations in the Philippines. Management and Engineering of Environment and Energy, IMT Atlantique Nantes, France.

[10]COES-SINAC. 2019. Estadística de Operación anual 2018. Lima-Peru.

[11]MINISTRY OF ENERGY AND MINES. 2020. Balance Nacional de Energía. Lima-Peru 